Research Journal of Animal Sciences 4 (1): 1-4, 2010

ISSN: 1993-5269

(C) Medwell Journals, 2010

\title{
Potentials of Jatropha Seeds as Substitute Protein in Nutrition of Poultry
}

\author{
${ }^{1}$ A.A. Annongu, ${ }^{1}$ M.A. Belewu and ${ }^{2}$ J.K. Joseph \\ ${ }^{1}$ Division of Nutritional Biochemistry and Toxicology, University of Ilorin, \\ P.O. Box 10004 Unilorin Post Office, Ilorin, Nigeria West Africa \\ ${ }^{2}$ Department of Food Science and Home Economics, University of Ilorin, \\ P.M.B. 1515, Nigeria
}

\begin{abstract}
An assessment of 5\% Jatropha curcas seed meal, JSM treated by combined physical and biochemical methods was conducted. About 144 days old Olympiad cockerel chicks were fed the variously treated JSM in 6 dietary treatments and their performance, biochemical and blood composition were evaluated in a month feeding trial. Results on performance showed no significant differences in feed intake and weight gain ( $p>0.05)$ with a marginal variation in feed efficiency relative to the reference diet $(p<0.05)$ and a very high mortality rate on the diet containing boiled and roasted JSM followed by fermentation. Some biochemical data analyzed showed no significant differences in all the indices measured except the blood cholesterol level and urea excretion ( $\mathrm{p}<0.05$ ). Also, no significant differences were recorded on the activities of AST and AP except ALT $(\mathrm{p}<0.05)$. Data on blood chemistry similarly indicated no significant differences in $\mathrm{PCV}, \mathrm{RBC}, \mathrm{HB}$ and the differentials of WBC counts ( $\mathrm{p}>0.05$ ) apart from the difference observed on WBC count $(\mathrm{p}<0.05)$. It could be inferred that treating JSM or its cake by most of the methods adopted could bring about detoxification and will have no adverse effect on the fed livestock. Further researches are being carried out to enable inclusion of Jatropha products/by-products at levels higher than the $5 \%$ used in this study.
\end{abstract}

Key words: JSM, cockerels, performance, biochemical indices, haematology, roasted, Nigeria

\section{INTRODUCTION}

Experiments on the use of lesser known feedstuffs which have valuable potentials as livestock and human food are on the increase in developing countries. This is aimed at avoiding the over dependence on the limited conventional feeds as key protein and energy feedstuffs for livestock. The high demand for maize, groundnut, soybean cake has given rise to increase in their prices and a concomitant cost of livestock feeds and its products. It has become necessary therefore to find alternatives to the orthodox feedstuffs in order to widen sources of raw materials.

It is for this reason that Jatropha curcas seed is being considered in this research. Jatropha, a multipurpose drought resistant shrub is native to tropical America but thrives throughout Africa, Asia, other tropical and subtropical countries. It also grows in a number of climatic zones including areas of low rainfall. Other attributes of Jatropha include easiness to establish, relatively quick growth rate and hardy ability to grow on marginal land and reclaim or restore eroded soils. Various parts of the plant hold potential for use as animal feed, use in medicine and so on. Jatropha produces large quantity of seeds per hectare ranging from 0.1-8.0 tons/ha/year (Heller, 1996). Preliminary studies on the nutritional value of Jatropha seeds showed that the presence of a cocktail of anti-nutritional factors in it namely phorbolesters, saponins, tannins, phytates, lectins, hydrocyanides, oxalate prevent its use in animal nutrition (Makkar and Becker, 1997).

Investigations on the use of the seeds have been mainly as potential source of oil as biodiesel to substitute fossil fuel in automobiles. The seeds contain about $60 \%$ oil. The cake remaining after oil extraction is used as manure to enrich soil for crops. The research in view tends to investigate the nutritional aspects of including physically and bio-chemically processed Jatropha curcas Seed Meal (JSM) in diets for cockerel chicks.

\section{MATERIALS AND METHODS}

Jatropha curcas seeds used in this experiment were obtained from ripened fruits harvested from Ilorin, Kwara state of Nigeria. Over $60 \mathrm{~kg}$ seeds were collected and sun-dried to constant weight before milling using an attrition miller. The meal was divided into equal parts

Corresponding Author: A.A. Annongu, Division of Nutritional Biochemistry and Toxicology, University of Ilorin, P.O. Box 10004 Unilorin Post Office, Ilorin, Nigeria West Africa 
Res. J. Anim. Sci., 4 (1): 1-4, 2010

Table 1: Composition of the experimental diet on as fed basis (\%) Diets

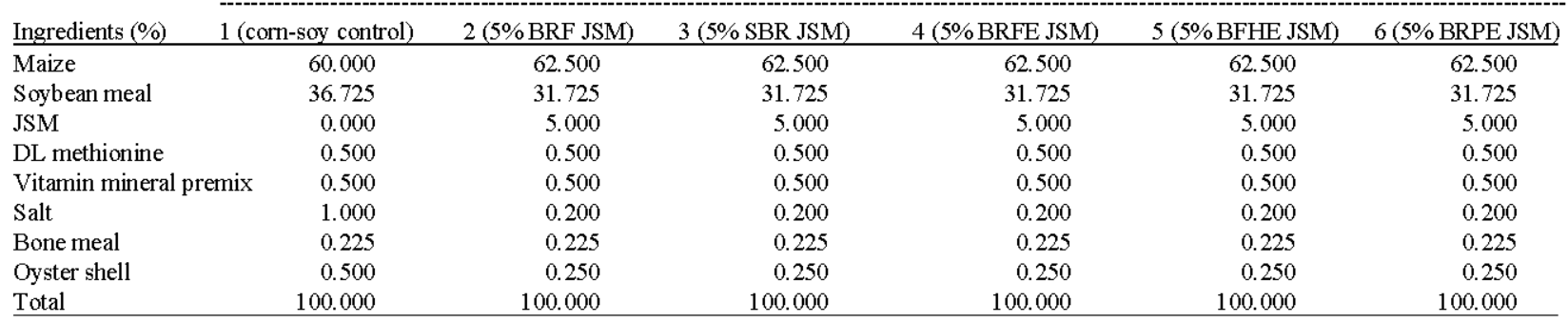

NB: 2-BRF-JSM = boiled, fermented Jatropha seed meal, 3-SBR = soaked, boiled and roasted JSM, BRFE = boiled, roasted and fermented JSM soaked in ethanol, BFHE = boiled, fermented JSM soaked in hexane and ethanol, 6-BRPE = boiled, roasted JSM soaked in petroleum ether and ethanol

of $12 \mathrm{~kg}$ and each part was subjected to different processing methods as enumerated: the reference diet (Adewuyi and Olatunji, 1995) was made of maizesoybeans basal ingredients while diet 2 contained JSM treated by boiling, roasting and fermenting, diet 3 had JSM processed by soaking, boiling and roasting, diets 4 and 5 contained JSM treated by boiling, roasting, fermenting and soaked in ethanol for $24 \mathrm{~h}$ and JSM processed by boiling, fermenting and soaked in equal volumes of hexane and ethanol for $24 \mathrm{~h}$, respectively. Diet 6 was treated by boiling, roasting and soaked in equal volumes of petroleum ether and ethanol for 1 day.

Soaking in tap water was done for 2 days while boiling was conducted for $60 \mathrm{~min}$. Roasting was carried out for $20 \mathrm{~min}$ while fermentation was conducted as described by Annongu et al. (1996). After soaking in the chemicals, JSM was sieved and pressed to separate the oil containing some of the anti-nutrients/toxins. The residual cake from the various treatments after oil extraction was sun-dried, pulverized before inclusion into the different diet mixtures. About 6 diets of equal protein and energy, $22 \%$ and $2800 \mathrm{kcal} \mathrm{kg}^{-1}$ were formulated. The variously treated JSM was included at 5\% level for all the diets. Table 1 shows the composition of the experimental diets on as fed basis. About 144 days old Olympiad cockerel chicks were randomly allotted to the 6 dietary treatments, each containing 24 chicks in three replicates following a completely randomized design. The chicks were housed in an electrically heated battery brooder cage and offered the experimental diets to appetite for a period of 1 month.

Performance characteristics: While the experiment lasted, data was collected on feed consumption, body weight gain, feed efficiency and rate of survival of the cockerels.

Biochemical indices: At the end of the experimental trial, blood samples were collected from 3 cockerels of each treatment that is from replicate A-C. Blood samples were collected in test tubes and centrifuged at $2500 \mathrm{rpm}$ to obtain clear sera. Serum total protein was determined by the biurette method described by Clowick and Kaplan (1955). Albumin was analysed by the method of Doumas and Biggs (1972) while creatinine was determined using the procedures of Scott (1965).

Blood total cholesterol level, urea, uric acid and globulin were determined according to the methods outlined by AMA (Adewuyi and Olatunji, 1995). Serum Aspartate aminotransferase (AST; EC 2.6.1.1) and Alanine aminotransferase (ALT; EC 2.6.1.2) activities were determined according to the colorimetric method of Reitman and Frankel (1959) while Alkaline Phosphatase (AP; EC 3.1.3.1) activity was determined by the kinetic method of Frajola et al. (1965).

Blood composition: Blood samples for haematological analyses were collected via the jugular vein into EDTA treated bottles. Packed Cell Volume, PCV was determined with a microhaematocrit centrifuge, Red Blood Cells, RBC and leucocytes, WBC counts were determined with a haemoxytometer. Haemoglobin content, HB was analyzed by the Wedemeyer and Yasutake (1977) method while the differential leucocyte counts were determined by counting stained blood smears with a light microscope (Leishmans model).

Statistics: Data collected were analyzed by ANOVA of a completely randomized design while treatment means were further separated using Duncan (1955) multiple range test.

\section{RESULTS AND DISCUSSION}

Results on performance parameters are shown in Table 2. There were no statistical significant differences in feed intake and weight gain of the cockerels at the end of the trial relative to the control group of birds $(\mathrm{p}>0.05)$. There were marginal differences in feed conversion ratios among the treatments $(\mathrm{p}<0.05)$. Highest mortality rate was recorded on the diet containing JSM treated by boiling, roasting followed by fermentation. The absence of 
Res. J. Anim. Sci., 4 (1): 1-4, 2010

Table 2: Performance response of cockerels to dietary treated JSM

\begin{tabular}{|c|c|c|c|c|c|c|}
\hline \multirow[b]{2}{*}{ Indices } & \multicolumn{6}{|l|}{ Diets } \\
\hline & 1 & 2 & 3 & 4 & 5 & 6 \\
\hline Mean daily feed intake $(\mathrm{g} / \mathrm{b} / \mathrm{day})$ & 133.30 & 93.30 & 70.00 & 100.00 & 103.00 & $100.00^{\mathrm{NS}}$ \\
\hline Mean daily wt gain $(\mathrm{g} / \mathrm{b} /$ day $)$ & 217.00 & 67.00 & 67.00 & 83.30 & 93.30 & $77.00^{\mathrm{NS}}$ \\
\hline Feed conversion ratio $(\mathrm{F} / \mathrm{G})$ & $0.61^{\mathrm{a}}$ & $1.30^{b}$ & $1.04^{b}$ & $1.20^{b}$ & $1.10^{b}$ & $1.29^{\mathrm{b}^{*}}$ \\
\hline Mortality rate $(\%)$ & 13.00 & 83.00 & 20.80 & 33.00 & 10.60 & 25.00 \\
\hline
\end{tabular}

${ }^{\mathrm{ab}}$ Mean in rows not sharing common letters differed significantly $(\mathrm{p}<0.05)$, NS: No Significant difference $(\mathrm{p}>0.05)$

Table 3: Influence of dietary processed JSM on some biochemical parameters in cockerels

\begin{tabular}{|c|c|c|c|c|c|c|}
\hline \multirow[b]{2}{*}{ Parameters } & \multicolumn{6}{|l|}{ Diets } \\
\hline & 1 & 2 & 3 & 4 & 5 & 6 \\
\hline Total protein $\left(\mathrm{g} \mathrm{L}^{-1}\right)$ & 54.33 & 48.67 & 54.33 & 48.67 & 43.33 & $42.67^{\mathrm{NS}}$ \\
\hline Albumin $\left(\mathrm{g} \mathrm{L}^{-1}\right)$ & 21.33 & 18.67 & 24.67 & 20.67 & 22.33 & $21.67^{\mathrm{NS}}$ \\
\hline Globulin $\left(\mathrm{g} \mathrm{L}^{-1}\right)$ & 33.00 & 30.00 & 29.67 & 28.00 & 21.00 & $21.00^{\mathrm{NS}}$ \\
\hline Cholesterol $\left(\mathrm{mmol} \mathrm{L}^{-1}\right)$ & $3.53^{\mathrm{a}}$ & $3.97^{\mathrm{b}}$ & $4.63^{b}$ & $4.47^{\mathrm{b}}$ & $4.00^{b}$ & $3.93^{b^{*}}$ \\
\hline Uric acid $\left(\mathrm{mmol} \mathrm{L}^{-1}\right)$ & 0.32 & 0.33 & 0.53 & 0.38 & 0.48 & $0.35^{\mathrm{NS}}$ \\
\hline Urea $\left(\mathrm{mmol} \mathrm{L}^{-1}\right)$ & $3.87^{\mathrm{ab}}$ & $2.20^{\mathrm{a}}$ & $2.73^{\mathrm{a}}$ & $2.00^{\mathrm{a}}$ & $3.20^{\mathrm{ab}}$ & $3.23^{\mathrm{ab}}$ \\
\hline Creatinine $\left(\mu \mathrm{mol} \mathrm{L} \mathrm{L}^{-1}\right)$ & 76.33 & 70.00 & 72.00 & 69.00 & 77.00 & $71.676^{\mathrm{NS}}$ \\
\hline AST $\left(\mathrm{IU} \mathrm{L}^{-1}\right)$ & 13.67 & 9.67 & 9.00 & 13.33 & 13.67 & $9.33^{\mathrm{NS}}$ \\
\hline $\operatorname{ALT}\left(\mathrm{IU} \mathrm{L}^{-1}\right)$ & $8.00^{\mathrm{a}}$ & $8.87^{\mathrm{a}}$ & $9.00^{\mathrm{a}}$ & $16.33^{b}$ & $14.67^{b}$ & $10.67^{b}$ \\
\hline $\mathrm{AP}\left(\mathrm{IU} \mathrm{L}^{-1}\right)$ & 88.00 & 103.67 & 102.33 & 110.00 & 108.33 & $102.33^{\mathrm{NS}}$ \\
\hline
\end{tabular}

Table 4: Effects of dietary treated JSM on haematology in cockerels

\begin{tabular}{|c|c|c|c|c|c|c|}
\hline \multirow[b]{2}{*}{ Parameters } & \multicolumn{6}{|c|}{ Diets } \\
\hline & 1 & 2 & 3 & 4 & 5 & 6 \\
\hline PCV (\%) & 26.00 & 26.30 & 20.67 & 20.30 & 25.30 & $20.00^{\mathrm{NS}}$ \\
\hline $\mathrm{WBC} \times 109 / \mathrm{L}$ & $8.40^{b}$ & $8.23^{b}$ & $7.10^{\mathrm{a}}$ & $7.16^{\mathrm{a}}$ & $9.53^{b}$ & $8.56^{b^{*}}$ \\
\hline $\mathrm{RBC} \times 1012 / \mathrm{L}$ & 6.70 & 6.43 & 5.07 & 5.37 & 6.70 & $5.86^{\mathrm{NS}}$ \\
\hline $\mathrm{HB}, \mathrm{g} \mathrm{dL}^{-1}$ & 4.57 & 4.00 & 3.57 & 3.83 & 4.57 & $3.37^{\mathrm{NS}}$ \\
\hline Neutrophils (\%) & 15.33 & 19.67 & 16.63 & 17.33 & 13.00 & $16.67^{\mathrm{NS}}$ \\
\hline Eosinophils (\%) & 0.67 & 0.33 & 0.67 & 0.67 & 1.00 & $0.67^{\mathrm{NS}}$ \\
\hline Lymphocytes (\%) & 84.00 & 79.33 & 82.53 & 81.67 & 86.00 & $82.33^{\mathrm{NS}}$ \\
\hline Monocytes (\%) & 0.50 & 0.67 & 0.67 & 0.33 & 0.50 & $0.67^{\mathrm{NS}}$ \\
\hline
\end{tabular}

significant difference in feed intake and weight gain in the cockerels receiving dietary treated JSM compared with the control diet suggested that treated JSM reduced or eliminated the phytotoxins in Jatropha that normally elicit deleterious effects in fed animals. The marginal differences in feed utilization efficiency and the highest mortality rate observed on the diet (Annongu et al., 1996) with JSM boiled, roasted and fermented could be explained in terms of the degree of efficiency of the various methods adopted to detoxify JSM.

Preliminary works (Makkar and Becker, 1999) opined that due to the myriad of toxins in the poisonous Jatrophap varieties, the cake, oil or its meal is not suitable for human or animal nutrition. However, in this study there appear to be prospect of using the poisonous varieties when adequate methods of detoxification are used. Table 3 shows influence of dietary JSM on some biochemical indices including some metabolites and enzyme activities in the fed birds. No significant differences were observed among the treatments in total protein, albumin or globulin contents $(p>0.05)$ except the blood cholesterol level $(\mathrm{p}<0.05)$. Similarly, no significant differences were recorded on the metabolites, uric acid and creatinine $(\mathrm{p}>0.05)$, urea excreted was significant $(\mathrm{p}<0.05)$. Enzyme activities measured by AST and $\mathrm{AP}$ were comparable with those of the reference diet ( $p>0.05$ ) apart from the activities of ALT which were significant relative to the control diet $(p>0.05)$. The lack of significant differences in most of the biochemical characteristics including the metabolites could means that the treatments adopted served to prevent the adverse effects inherent in raw JSM when fed untreated (Guyton and Hall, 2000). Variations in blood cholesterol levels and urea secretion recorded in this study could be attributed to the residual effects of Jatropha toxicants acting in concert with the dietary nutrients to bring about the differences.

Blood composition indices of $\mathrm{PCV}, \mathrm{RBC}, \mathrm{WBC}, \mathrm{HB}$ and the differential counts of WBC given by neutrophils, eosinophils, lymphocytes and monocytes are shown in Table 4. Apart from differences observed on the leucocytes among the treatments $(p>0.05)$, no significant differences were recorded on all the haematological parameters $(\mathrm{p}>0.05)$. The similarity in blood parameters of cockerels receiving the test feedstuff compared with the parameters of the control diet could be due to the improved status of the dietary JSM following the treatments. 


\section{CONCLUSION}

It could be inferred that treating JSM by combined methods of physical and bio-chemical as shown in this data has prospect in improving the nutritional value of JSM for monogatric livestock. Further research will be carried out to improve the nutritional of Jatropha seeds so that inclusion at higher percentages would be possible.

\section{REFERENCES}

Adewuyi, J.O. and P.O. Olatunji, 1995. Manual of Practical Haematology for the MBBS Course. University of Ilorin, Ilorin, Nigeria.

Annongu, A.A., U.T. Meulen, J.O. Atteh and D.F. Apata, 1996. Toxikologische beurteilung von nativem und industriell fermentiertem schibutter-oelkuchen fuer die fuetterung von broilern. Arch. Gefluegelkunde, 60: $221-226$.

Clowick, S.P. and N.O. Kaplan, 1955. Methodology in Enzymology. 2nd Edn., Academic Press, New York.

Doumas, B.T. and H.G. Biggs, 1972. Determination of Serum Albumin. In: Standard Methods of Clinical Chemistry, Cooper, G.A. (Ed.). Vol. 7, Academy Press, New York, pp: 175-188.

Duncan, D.B., 1955. Multiple range and multiple F-tests. Biometrics, 11: 1-42.

Frajola, W.T., R.D. Williams and R.A. Austin, 1965. The kinetic spectrophotometric assay for serum alkaline phosphatase. Am. J. Clin. Pathol., 43: 261-264.
Guyton, A.C. and J.E. Hall, 2000. Textbook of Medical Physiology. 10th Edn., W.B. Saunders Company, Philadelphia, USA., pp: 782-783.

Heller, J., 1996. Phytic Nut, Jatropha curcas Promoting the Conservation and Use of Underutilized and Neglected Crops. International Plant Genetic Resources Institute, Rome.

Makkar, H.P.S. and K. Becker, 1997. Nutrients and antiquality factors in different morphological parts of Moringa oleifera tree. J. Agric. Sci., 128: $311-322$.

Makkar, S.P.S. and K. Becker, 1999. Plant toxic and detoxification methods to improve feed quality of tropical seeds. Asian-Aust. J. Anim. Sci., 12: $467-480$.

Reitman, S. and S. Frankel, 1959. Acolorimetric method for the determination of serum glutamic oxaloacetic and glutamic pyruvic transaminases. Am. J. Clin. Pathol., 28: 56-61.

Scott, C., 1965. Plasma creatinine determination: A new and specific reaction method. Scandnavian J. Lab. Invest., 17: 381-385.

Wedemeyer, G.A. and W.T. Yasutake, 1977. Clinical methods for the assessment of the effects of environmental stres of fish health. United States Technical Papers and United States Fish Wildlife Services 89, 1-18. http://mdl.csa.com/partners/ viewrecord.php?requester $=$ gs \& collection $=$ ENV \& recid $=5272462$. 